\title{
Equine placentitis
}

\author{
Mats H. T. Troedsson ${ }^{1,2}$ and Lynda M. J. Miller ${ }^{2}$ \\ ${ }^{1}$ Maxwell H. Gluck Equine Research Laboratory, Department of Veterinary Science, University of Kentucky, Lexington, KY, USA \\ 2 Al Shaqab, Qatar Foundation, Education City, Doha, Qatar
}

\begin{abstract}
Summary: Placentitis is a common cause of late term abortion in mares. Based on morphologic lesions and pathogenesis, four different types of placentitis have been identified: (1) ascending placentitis (2) focal mucoid placentitis (3) diffuse placentitis and (4) multifocal placentitis. In most cases, infection of the placenta results in subsequent infection of the fetus and the release of prostaglandins from the inflamed placenta, which ultimately leads to abortion or delivery of a premature foal. Affected foals may experience accelerated fetal maturation in response to the inflammatory environment. They are typically delivered prematurely, but are often mature enough to survive in the extrauterine environment. It has been suggested that indirect stimulation of the fetal hypothalamic-pituitary-adrenal axis by pro-inflammatory cytokines is responsible for precocious fetal maturation and that delaying premature labor long enough to allow accelerated fetal maturation to occur may improve foal survival rates. To achieve this goal, it is necessary to promptly diagnose and effectively treat the disease before clinical signs are observed. No single sample test appears to have sufficient specificity and sensitivity to accurately detect subclinical cases of placentitis. Therefore the development of a panel of diagnostic tests that accurately indicate inflammation as well as placental insult is needed. Transrectal and transabdominal ultrasound, combined with endocrinological (progesterone, estrogen and relaxin), and inflammatory biomarkers such as acute phase protein assays, may provide additional tools for diagnosing subclinical placentitis and monitoring progression of the disease in mares. These tests could be used to regularly monitor placental health during late pregnancy, and allow us to treat the condition at an early stage. Treatment strategies for mares with ascending placentitis are directed at several factors including combating infection (antibiotics), reducing inflammation (NSAIDs) and controlling myometrial activity (progestins). Although selected antibiotics cross the placenta, fetal fluid concentrations are consistently significantly lower than in serum, often resulting in a suppression rather than elimination of bacterial growth in the placenta and the allantoic fluid. It should therefore, be of high priority to identify antibiotics that can be administered in doses that cross the placenta and maintain sufficient concentrations for a sustained duration of time. A recent study suggests that when mares with placentitis are treated successfully, the future athletic performance of their foals does not appear to be affected.
\end{abstract}

Keywords: equine / reproduction / placenta / infection / pregnancy / abortion

\section{Plazentitis des Pferdes}

Eine häufige Ursache des Spätabortes bei der Stute ist eine Plazentitis. Basierend auf morphologischen Läsionen und der Pathogenese können vier Plazentitistypen unterschieden werden: 1. aszendierende Plazentitis, 2. fokale mukoide Plazentitis, 3. diffuse Plazentitis und 4. multifokale Plazentitis. In den meisten Fällen resultiert aus einer Infektion der Plazenta die Infektion des Fötus und die Freisetzung von Prostaglandinen aus der entzündeten Plazenta, was letztlich zum Abort bzw. zur Frühgeburt führt. Als Reaktion auf die entzündliche Umgebung zeigen betroffene Fohlen eine beschleunigte fetale Reifung. Sie werden typischerweise vorzeitig geboren, sind aber oft reif genug, um in der extrauterinen Umgebung zu überleben. Es wird vermutet, dass eine indirekte Stimulation der fetalen Hypothalamus-Hypophysen-Nebennieren-Achse durch proinflammatorische Zytokine für eine frühzeitige fetale Reifung verantwortlich ist und dass die Verzögerung vorzeitiger Wehen lang genug ist, um eine beschleunigte fetale Reifung zu erlauben, so dass die Überlebensrate der Fohlen verbessert ist. Um dieses Ziel zu erreichen, sind eine unverzügliche Diagnose und eine effektive Behandlung der Erkrankung notwendig, bevor klinische Symptome auftreten. Kein Test allein scheint eine ausreichende Spezifität und Sensitivität zu haben, um eine subklinische Plazentitis präzise zu diagnostizieren. Daher ist es notwendig, einen Algorithmus diagnostischer Test zu entwickeln, um sorgfältig und genau sowohl Entzündungen als auch Verletzungen der Plazenta zu erfassen. Transrektale und transabdominale Sonographie, kombiniert mit endokrinologischen Tests (Progesteron, Östrogen und Relaxin) und Entzündungsmarkern (Akut-Phase-Protein-Test), bieten eine zusätzliche Möglichkeit subklinische Plazentitiden zu diagnostizieren und den Krankheitsverlauf der Stute zu überwachen. Diese Tests können eingesetzt werden, um die Plazentagesundheit während der späten Trächtigkeit regelmäßig zu überwachen und erlauben eine frühzeitige Therapie. Die Behandlungsstrategien bei Stuten mit aszendierender Plazentitis hängen von mehreren Faktoren ab und schließen die Infektionsbekämpfung (Antibiotika), die Entzündungshemmung (NSAIDs) und die Kontrolle der myometrialen Aktivität (Progestine) ein. Obwohl ausgewählte Antibiotika die Plazenta passieren, ist deren Konzentration in fetalen Flüssigkeiten stets signifikant geringer als im Serum. Dies führt häufig eher zu einer Suppression als zur Elimination bakteriellen Wachstums in der Plazenta und der Allantoisflüssigkeit. Daher ist es von hoher Priorität, Antibiotika auszuwählen, die in einer Dosis, die die Plazenta passiert, appliziert werden können und deren Konzentration in einer ausreichend langen Zeit erhalten bleibt. Eine jüngste Studie konnte zeigen, dass, wenn Stuten mit einer Plazentitis erfolgreich behandelt worden sind, die zukünftige sportliche Leistungsfähigkeit ihrer Fohlen nicht beeinträchtigt zu sein scheint.

Schlüsselwörter: Stute / Reproduktion / Plazenta / Infektion / Trächtigkeit / Abort

Citation: Troedsson M. H. T., Miller L. M. J. (2016) Equine placentitis. Pferdeheilkunde 32, 49-53

Correspondence: Corresponding author: Mats H. T. Troedsson, DVM, PhD, DACT, DECAR, Professor, Maxwell H. Gluck Equine Research Center, University of Kentucky, Lexington, KY, USA; E-mail: m.troedsson@uky.edu

\section{Introduction}

Placentitis is a common cause of late term abortion in mares and poses a significant threat to fetal and neonatal viability (Giles et al. 1993). Bacterial agents commonly associated with the occurrence of placentitis are Streptococcus equi subspecies zooepidemicus, Escherichia coli, Klebsiella pneumoniae, Pseudomonas aeruginosa, Streptococcus equisimilis, Enterobacter agglomerans, alpha-hemolytic Streptococcus 
spp., Leptospira spp, Crossiella equi, and Amycolatopsis spp whereby streptococci predominate. Based on morphologic lesions and pathogenesis, four different types of placentitis have been identified.

\section{Ascending placentitis}

Bacteria are thought to enter the uterus via the cervix through an ascending vaginal infection. Placentitis usually starts at the cervical star and spreads into the uterus from there. Mares afflicted with ascending placentitis may abort with no clinical signs or the may show classic signs of placentitis including premature mammary development and/or mucopurulent vaginal discharge.

\section{Focal mucoid placentitis}

The most common cause of Nocardioform placentitis is gram-postitive branching bacilli, Crosiella equi and Amycolatopsis species (Donahue and Williams 2000). Other less common causes of focal mucoid placentitis include Staphylococcus spp., Pantoea agglomerans, Cellulosimicrobium cellulans, and Enterobacter spp. The condition was first described in central Kentucky, where it is a common cause of abortion in certain years. The pathogenesis, route of infection or risk factors have not been identified for this type of placentitis. Typical gross lesion for focal mucoid placentitis includes a large amount of exudate present on the chorionic surface that is usually thick and tenacious.

\section{Diffuse placentitis}

Diffuse placentitis is most often associated with Leptospira spp., less commonly associated with Salmonella spp., and rarely associated with Histoplasma spp. and Encephalitozoon spp. These agents reach the placenta through the systemic circulation, resulting in amnionitis, funisitis and acute inflammation of the chorioallantois (Donahue and Williams 2000).

\section{Multifocal placentitis}

This is a rare form of placentitis that has been associated with fungi or bacteria (Hong et al. 1993).

Infection of the placenta results in subsequent infection of the fetus and in the release of prostaglandins from the inflamed placenta, which ultimately leads to abortion or delivery of a premature foal (LeBlanc et al. 2002). Focal mucoid placentitis appears to be an exception to this suggested pathophysiology as the bacteria and resulting inflammation is restricted to the chorioallantois and the interphase between the chorion and the endometrium (Hong et al. 1993). Regardless of the type of placentitis, placental separation can cause "starvation" of the foal resulting in abortion or birth of an undersized foal prematurely or at term. This is particularly common in focal mucoid placentitis.

Foals affected by placentitis may experience accelerated fetal maturation. They are typically delivered prematurely, but will be mature enough to survive in the extrauterine environment. It has been suggested that indirect stimulation of the fetal hypothalamic-pituitary-adrenal axis by pro-inflammatory cytokines is responsible for precocious fetal maturation (Besedovsky and del Ray 1996). If this is true, delaying premature labor long enough to allow accelerated fetal maturation to occur may improve foal survival rates. To achieve this goal, it is necessary to promptly diagnose and effectively treat the disease before clinical signs are observed. When these signs are present, it is often too late to effectively treat the condition.

\section{Diagnosis of Placentitis}

The most common clinical signs of placentitis in mares are premature udder development ( \pm streaming of milk) and vulvar discharge. Transrectal and transabdominal ultrasound, often combined with endocrinological assays, provide additional tools for diagnosing and monitoring progression of placentitis in mares.

\section{Ultrasonographic monitoring of the placenta:}

Transrectal ultrasonography of the caudal allantochorion in late gestational mares provides an excellent image of the placenta close to the cervical star (Figure 1) (Renaudin et al. 1997). This part of the placenta is most commonly affected in mares with ascending placentitis. Normal values for the combined thickness of the uterus and placenta (CTUP) have been established (Table 1) (Renaudin et al. 1997, Troedsson et al. 1997). Increases in CTUP $>8 \mathrm{~mm}$ between day 271 and $300,>10 \mathrm{~mm}$ between day 301 and 330 , and $>12 \mathrm{~mm}$ after day 330 have been associated with placental failure and pending abortion (Troedsson et al. 1997, Renaudin et al. 1999).

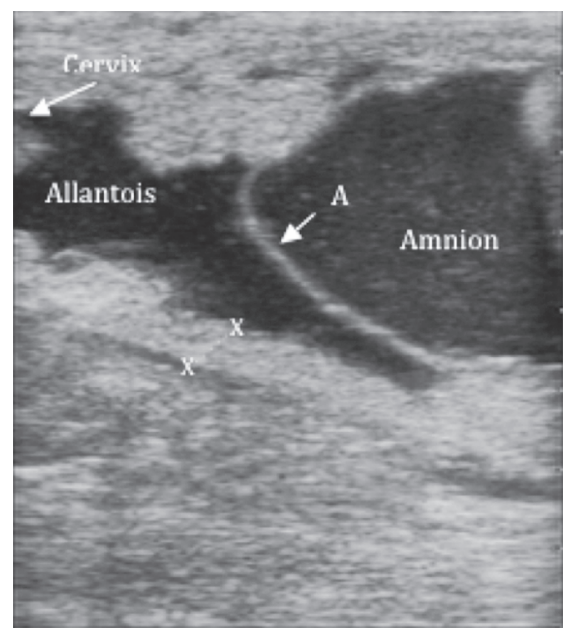

Fig 1 Transrectal ultrasonography of the caudal part of the placenta in a late gestational mare. ( $A=$ amniotic membrane; $\mathrm{x}-\mathrm{x}=\mathrm{CTUP}$ ).

Transrektale Sonographie des kaudalen Abschnittes der Plazenta während der späten Trächtigkeit bei der Stute $(A=$ Amnionmembran; $x-x=$ CTUP)

Tab. 1 Normal upper limits for the combined thickness of the uterus and the placenta (CTUP) during late gestation. (Adapted from Renaudin et al. (1997). I Normale Obergrenzen für die CTUP (kombinierte Dicke von Uterus und Plazenta) während der späten Trächtigkeit (adaptiert von Renaudin et al. (1997)

\begin{tabular}{cc}
\hline Gestation length & Normal CTUP \\
\hline $151-270$ days & $<7 \mathrm{~mm}$ \\
$271-300$ days & $<8 \mathrm{~mm}$ \\
$301-330$ days & $<10 \mathrm{~mm}$ \\
$331-$ & $<12 \mathrm{~mm}$
\end{tabular}


In some cases, hyperechoic fluid (purulent material) can be seen separating the uterus and the placenta (Figure 2). Additional parameters that can be evaluated using transrectal ultrasonography include changes in the amniotic membrane and character of fetal fluids. In normal mares, allantoic fluid is commonly hypoechoic with some specular material, while amniotic fluid is frequently a shade more hyperechoic (gray) than allantoic fluid. Marked changes in these fluid characteristics may indicate the presence of a placental infection or stress to the fetus.

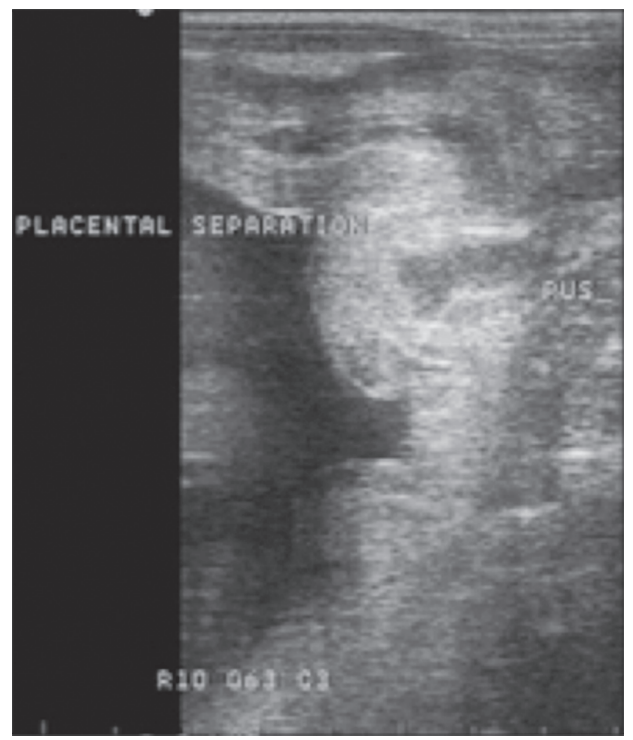

Fig. 2 Placental separation and accumulation of purulent material at the cervical star area in a mare with ascending placentitis. Plazentaablösung und Akkumulation eitrigen Materials im Bereich des Zervikalsterns bei einer Stute mit aszendierender Plazentitis

Transabdominal ultrasonography can also be a useful tool for placental evaluation in mares with suspected placentitis (Pipers and Adams-Brendemuehl 1984, Reef et al. (1996). Placental separation and purulent material at the ventral aspect of the base of the gravid horn and the junction of the uterine body can be observed in mares with focal mucoid placentitis. This finding can only be identified using transabdominal ultrasonography.

Serial ultrasonographic evaluations during late gestation have allowed us to more effectively treat placentitis and have improved the outcome in many cases (Troedsson and Zent 2003). However, it may not be practical to scan every mare repeatedly during late gestation. In addition, early stages of placentitis can be missed during ultrasonographic examination, and the technique is also prone to false positive diagnoses, resulting in unnecessary treatment. In the absence of an accurate and practical method to detect early, subclinical cases of placentitis, it has become increasingly common to treat pregnant mares with antibiotics for 5-7 days each month during late gestation. The long term risk of developing widespread bacterial resistance against antibiotics and the development of "super-bugs" should be of great concern, not only to the breeding industry, but to veterinary medicine as well as public health. Additional diagnostic tools are therefore, needed to accurately identify pregnant mares with early stages of placentitis and specifically target these mares for treatment.

\section{Endocrine Monitoring of the Placenta}

The equine placenta is part of an endocrine fetal-placental interaction, which synthesizes and metabolizes progestogens (Pashen 1984). This endocrine function is important for maintenance of pregnancy after the endometrial cups and the secondary corpora lutea regress around day 120-150 of gestation. Fetal-placental progesterone is rapidly metabolized to $5 \alpha$-pregnanes. Mares with placental pathology may have increased plasma concentrations of progestogens as a result of stress to the fetal placental unit (Rossdale et al. 1991, Stawicki et al. 2002). Unfortunately, $5 \alpha$-pregnanes are not readily assayed in a commercial setting, so diagnosis of placental disease using $5 \alpha$-pregnane concentrations is not possible. There is however, cross-reactivity between 5 - pregnanes and progesterone using some commercial radioimmunoassays for progesterone. In recent studies, using an experimental model to induce placentitis, it was found that mares that develop a chronic form of placentitis responded with increased plasma progesterone concentrations (Sheerin et al. 2003). Conversely, mares that developed acute placentitis and abortion soon after infection experienced a rapid drop in plasma progesterone concentrations. It was suggested that measurement of repeated samples of plasma progesterone concentrations in mares with placentitis might be a useful method to identify mares that may abort or deliver prematurely. Recent research in the author's laboratory does not support the use of progesterone as a sensitive marker for placentistis or placental wellbeing (unpublished observations). The discrepancies between the studies may be explained by variations in cross reactivity of progestogens among assays.

The equine gonads secrete large quantities of androgens, particularly dehydroepiandrosterone (DHEA) which serves as a precursor for the synthesis of estrogens by the equine placenta (Pashen 1984). Ordinarily, DHEA is rapidly and effectively metabolized by the placenta to estrogens by placental aromatase; however, some DHEA, particularly the conjugated DHEA-sulfate is present in maternal serum and has been measured during pregnancy in mares (Rance and Park 1978).

Serum estrogen concentrations are elevated in pregnant mares between 70-310 days of gestation. The predominant estrogens in pregnant mares are estrone, equilin, equilenin, estradiol-17ß, and estradiol-17 $\alpha$. Determination of serum concentrations of estrone sulfate has been suggested to be useful in determining fetal well being, and more recently, to monitor placental insult (Kashman et al. 1988). Douglas (2004) observed that mares aborting from placentitis had serum estrogen concentrations below those normally detected in pregnant mares Recent research suggests that estradiol$17 \beta$ sulfate concentration drops rapidly following experimentally induced placentitis (Canisso et al. 2012). This finding supports the observations by Douglas (2004) and needs to be further explored in naturally occurring placentitis.

Relaxin is produced by the equine placenta, and can be detected in peripheral blood plasma from day 80 of gestation and throughout the pregnancy (Stewart et al. 1982). The role of relaxin during pregnancy is not fully understood, but there is some evidence that placental relaxin production is compromised in mares at risk of aborting their fetuses (Ryan et al. 1999). However, there is not a commercial test available for equine relaxin. 


\section{Other diagnostic markers of placental inflammation}

Serum amyloid $A(S A A)$ is a major acute phase protein usually displaying low serum concentrations in healthy horses. In response to inflammation however, SAA concentrations can increase rapidly with large amplitude. In healthy pregnant mares, SAA remains low throughout gestation while showing a significant increase within 12 hours of parturition and return to base level within 60 hours postpartum (da Silva et al. 2011 ). Interestingly, levels of SAA in peripheral blood have been reported to increase in mares affected by placentitis (Canisso et al. 2014). However, SAA is a non-specific biomarker of inflammation with significant increase observed during other sources of inflammation, and even after vaccination. This finding suggests a limitation of using SAA alone to diagnose placentitis.

In summary, no single sample test appears to have sufficient specificity and sensitivity to accurately detect early subclinical cases of placentitis. The development of a panel of diagnostic tests that accurately indicate inflammation as well as placental insult is therefore needed. These tests could be used to regularly monitor placental health during late pregnancy, and allow us to be able to treat the condition at an early stage.

\section{Treatment of Equine Placentitis}

Treatment strategies for mares with ascending placentitis are directed at combating infection, reducing inflammation and controlling myometrial activity. Antibiotic therapy is an essential first step in treating placentitis. In vivo microdialysis has been used to detect concentrations of commonly used drugs in allantoic fluid of pregnant pony mares (Macpherson 2005). Penicillin, gentamicin and trimethoprim sulfamethoxazole were present in allantoic fluid, but importantly at lower concentrations than present in serum. Concentrations of penicillin in allantoic fluid achieved the minimum inhibitory concentration (MIC) against Streptococcus equi subspecies zooepidemicus. Gentamicin concentrations in allantoic fluid were adequate to be effective against Escherichia coli or Klebsiella pneumoniae. Furthermore, the duration of these elevated concentrations were short, which may explain why mares with placentitis need to be treated for the duration of their pregnancy, and that over $60 \%$ of mares that had been treated for placentitis still cultured positive after foaling (Diaw et al. 2010). Antibiotic induced suppression rather than elimination of bacteria carries an obvious risk for the development of multi-resistant bacteria, which may result in problems of much higher magnitude than what we are confronted with today. In light of this threat, it should be of high priority to identify a broad spectrum antibiotic or combination of antibiotics that can be administered in doses that cross the placenta and maintain sufficient concentrations for a sustained duration of time.

Several studies in humans and non-human primates provide evidence that pro-inflammatory cytokines play a key role in the pathogenesis of infection-associated preterm delivery (Dudley and Trautman 1994). Bacteria or bacterial products in the fetal membranes stimulate cell-mediated immune mechanisms with subsequent release of pro-inflammatory cytokines from macrophages and the decidua. In turn, pro- inflammatory cytokines stimulate release of prostaglandins E2 (PGE2) and F2 $\alpha$ (PGF2 $\alpha$ ) from the endometrium. Prostaglandins then initiate uterine contractions. Anti-inflammatory and immunomodulatory therapies have been shown to suppress inflammatory components of preterm labor in experimental models (Sadowsky et al. 2000 and 2003). Studies indicate that combined therapy is necessary to stem the bacterial infection as well as to suppress the subsequent inflammatory response.

Treatment with progestins has long been advocated to promote uterine quiescence in mares with uterine pathology. Daels and co-workers (1996) tested the effects of progesterone $(300 \mathrm{mg}, \mathrm{IM}, \mathrm{SID})$ and altrenogest $(0.088 \mathrm{ug} / \mathrm{kg}$ PO, SID), a synthetic progestin, on pregnancy maintenance in mares treated with the prostaglandin analog, cloprostenol. Five of eight mares (63\%) in the progesterone-treated group maintained pregnancies after cloprostenol treatment. All eight mares $(100 \%)$ treated with altrenogest maintained pregnancies. None of the control mares $(0 \%)$ maintained pregnancies after cloprostenol treatment. Although progestins may not totally prevent abortion in all mares with placentitis, it was suggested to reduce abortions when combined with antibiotics in mares with experimentally induced placentitis (Bailey et al. 2010).

Work from a large scale clinical trial examined the efficacy of multi-pronged, longterm therapy for treating equine placentitis (Troedsson et al. 2003). Investigators examined records of 477 mares over 6 years. Fifteen mares were diagnosed with placentitis. Criteria for treatment included increased thickness of the uteroplacental unit using transrectal ultrasound, placental separation and/or vulvar discharge and udder development. Mares were treated until abortion or delivery of a foal with a combination of systemic antibiotics (trimethoprim sulfa, ceftiofur or penicillin and gentimicin), altrenogest and non-steroidal anti-inflammatory agents. Twelve of fifteen (84\%) treated mares carried their foals to term and 11 of 15 (73\%) delivered live foals. Birth weights of surviving foals from mares treated for placentitis were similar to foals from non-affected mares. Similar results were found in a prospective and controlled study on treatment of mares with experimentally induced placentitis (Bailey et al. 2010). Data from these studies suggest that long term antibiotic and antiinflammatory treatment may positively impact pregnancy outcome in mares with placentitis. Limited data is available on the effect of foal illness and placentitis on subsequent athletic performance of the horse later in life. In a recent study, racing performance of foals from mares treated for placentitis was compared to matched foals from control mares with no signs of placentitis. This study indicated that the athletic performance of Thoroughbred racehorses out of mares with placentitis did not differ from paired controls (Hughes et al. 2014). Further and more extensive studies are needed to confirm this conclusion.

\section{References}

Bailey C. S., Macpherson M. L., Pozor M. A., Troedsson M. H., Benson S., Giguere S., Sanchez L. C., Leblanc M. M., Vickroy T. W. (2010) Treatment efficacy of trimetoprim sulfamethoxazole, pentoxifylline and altrenogest in experimentally induced equine placentitis. Theriogenology 74, 402-412 
Besedovsky H. O., del Rey A. (1996) Immune-neuro-endocrine interactions: facts and hypotheses. Endocrine Reviews. 17(1):64-102.

Canisso I. L., Ball B. A., Troedsson M. H. T., Klein C., Stanley S. D. (2012) Diagnostic markers for experimentally induced placentitis in the mare. J. Eq. Vet. Sci. 32, 73

Canisso I. F., Ball B. A., Troedsson M. H. T., Cray C., Davolli G. M., Squires E. L., Williams N. M. (2014) Acute phase proteins and blood leukocyte counts in mares with experimentally induced ascending placentitis. J. Eq. Vet. Sci. 34, 215

Daels P. F., Besognet B., Hansen B., Mohammed H., Odensvik K., Kindahl H. (1996) Effect of progesterone on prostaglandin F2 alpha secretion and outcome of pregnancy during cloprostenolinduced abortion in mares. Am. J. Vet. Res. 57, 1331-1337

Diaw M., Bailey C. S., Schlafer D., Pozor M., Troedsson M. H. T., Benson S., Macpherson M. L. (2010) Characteristics of endometrial culture and biopsy samples taken immediately postpartum from normal mares compared with those from mares with induced placentitis. Anim. Reprod. Sci. 121, S369-S370

Donahue J. M., Williams N. M. (2000) Emerging causes of placentitis and abortion. Vet. Clin. North Am. Equine Pract. 16, 443-456

Douglas R. H. (2004) Endocrine diagnostics in the broodmare: What do you need to know about progesteins and estrogens. In Proceedings of the Society for Theriogenology p. 106-115

Dudley D. J., Trautman M. S. (1994) Infection, inflammation, and contractions - the role of cytokines in the pathophysiology of preterm labor. Seminars in Reprod. Endocrin. 12, 263-272

Giles R. C., Donahue J. M., Hong C. B., Tuttle P. A., Petrites-Murphy M. B., Poonacha K. B., Roberts A. W., Tramontin R. R., Smith B., Swerczek T. W. (1993) Causes of abortion, stillbirth, and perinatal death in horses: 3,527 cases (1986-1991). J. Am. Vet. Med.Assoc. 203, $1170-1175$

Hong C. B., Donahue J. M., Giles R. C., Petrites-Murphy M. B., Poonacha K. B., Roberts A. W., Smith B., Tramontin R. R., Tuttle P. A., Swerczek T. W. (1993) Etiology and pathology of equine placentitis. Vet. Diag. Invest. 5, 56-63

Hughes S., Stowe C. J., Troedsson M. H. T., Ball B. A., Squires E. L. (2014) The athletic performance of thoroughbred racehorses out of mares with suspected placentitis during gestation. J. Eq. Vet. Sci. 34, 514-519

Kashman L. H., Hughes J. P., Stabenfeldt G. H. Starr M. D., Lasley B. L. (1988) Estrone sulfate concentrations as an indicator of fetal demise in horses. Am. J. Vet. Res. 49, 184-187

LeBlanc M. M., Giguere S., Braver K., Paccamonti D. L., Horohov D. W., Lester G. D., O'Donnell L. J., Sheerin B. R., Pablo L., Rodgerson D. H. (2002) Premature delivery in ascending placentitis is associated with increased expression of placental cytokines and allantoic fluid prostaglandins E-2 and F-2 $\alpha$. Theriogenology 58, 841-844

Macpherson M. L. (2005) Treatment strategies for mares with placentitis. Theriogenology. 64:528-534

Pashen R. L. (1984) Maternal and foetal endocrinology during late pregnancy and parturition in the mare. Equine Vet. J. 16, 233-238

Pipers F. S., Adams-Brendemueh/ C. S. (1984) Techniques and applications of transabdominal ultrasonography in the pregnant mare. J. Am. Vet. Med. Assoc. 185, 766-771
Rance T. A., Park B. K. (1978) Measurement of estrone, equilin and dehydroepiandrosterone in peripheral plasma of pregnant pony mares by radioimmunoassay. J. Steroid Biochem. Molecular. Biol. 9, 1065-1069

Reef B. V., Vaala W. E., Worth L. T., Sertich P. L., Spencer P. A. (1996) Ultrasonographic assessment of fetal well-being during late gestation: development of an equine biophysical profile. Equine Vet. J. 28, 200-208

Renaudin C. D., Troedsson M. H. T, Gillis C. L., King V. L., Bodena A. (1997) Ultrasonographic evaluation of the equine placenta by transrectal and transabdominal approach in the normal pregnant mare. Theriogenology. 47, 559-573

Renaudin C. D., Liu I. K. M., Troedsson M. H. T., Schrenzel M. D. (1999) Transrectal ultrasonographic diagnosis of ascending placentitis in the mare: a report of two cases. Equine Vet. Educ. 11, 69-74

Rossdale P. D., Ousey J. C., Cottrill C. M., Chavatte P., Allen W. R., McGladdery A. J. (1991) Effects of placental pathology on maternal plasma progestagen and mammary secretion calcium concentrations and on neonatal adrenocortical function in the horse. J. Reprod. Fert. Suppl. 44, 579-590

Ryan P. K., Bennet-Wimbush K., Vaala W. E., Bagnell C. A. (1999) Relaxin as a biochemical marker of placental insufficiency in the horse: a review. Pferdeheilkunde 15, 622-626

Sadowsky D. W., Haluska G. J., Gravett M. G., Witkin S. S., Novy M. J. (2000) Indomethacin blocks interleukin 1 beta-induced myometrial contractions in pregnant rhesus monkeys. Am. J. Obstetrics Gynecol. 183, 173-180

Sadowsky D. W., Novy M. J., Witkin S. S., Gravett M. G. (2003) Dexamethasone or interleukin-10 blocks interleukin-1 beta-induced uterine contractions in pregnant rhesus monkeys. Am. J. Obstetrics Gynecol. 188, 252-263

Sheerin P. C., Morris S., Kelleman A. A., Stawicki R., Sheerin B. R., LeBlanc M. M. (2003) Diagnostic efficiency of transrectal ultrasonography and plasma progestin profiles in identifying mares at risk for premature delivery. In Proceedings of the AAEP, Focus in Equine Reproduction. p. 22-23

da Silva M. A. C., Canisso I. F., Johnson A. E. M., Divers T. J. (2011) Parturition increases serum amyloid $A$ concentration in healthy pregnant mares. Clin. Theriogenology 3, 355.

Stawicki R. J., Ruebel H., Hansen P. J., Sheerin B. R., O'Donnell L. J., Lester G. D., Paccamonti D. L., LeBlanc M. M. (2002) Endocrinological findings in an experimental model of ascending placentitis in the mare. Theriogenology 58, 849-852

Stewart D. R., Stabenfeldt G. H., Hughes J. P. (1982) Relaxin activity in foaling mares. J. Reprod. Fert. Suppl. 32, 603-609

Troedsson M. H. T., Renaudin C. D., Zent W. W., Steiner J. V. (1997) Transrectal ultrasonography of the placenta in normal mares and mares with pending abortion: a field study. Proc. AAEP 43, 256258

Troedsson M. H. T., Zent W. W. (2003) Clinical ultrasonographic evaluation of the equine placenta as a method to successfully identify and treat mares with placentitis. In Proceedings of a Workshop on the Equine Placenta. Lexington, KY. p. 66-67 